\title{
MULTIFUNCTIONALITY OF FORESTRY AS BASIS FOR CREATING GROSS INNOVATIONAL FORESTRY PRODUCT
}

The article is devoted to theoretical and methodological issues of defining the essence, role and place of multifunctional forest economy (MFFE) from the perspective of the scientific rationale of the state forest policy, which contributes to transference of the forest sector to the innovative basis with the emphasis on the regeneration issues. The system-regeneration approach is used as a methodological tool, which is the combination of principles and analysis of the forest sector as a complicated social-economical system based on the methodology of the regeneration process.

On the basis of objective economic laws and regulations, a political-economic analysis is carried out to find out the system interrelation of the quality of forest resource use and productivity of social labour in the forest sector. Common features in the circulation of the functions of forestry capable of creating a special form of an innovation, gross innovational forestry product are identified. A model of a multifunctional forestry providing an opportunity to predict the characteristics of innovational products in complex systems is suggested. This model makes the basis for research of the innovative changes potentional for modernization of the innovative forest product. 
Keywords: state forest policy, mono- and multifunctionality of forestry, law of transforming quality into quantity, sustainable development, regeneration approach, concept of improving the forest management quality, gross innovational forestry product, generalized model of multifunctional forestry

The importance of the problem of general forestry regeneration, implemented due to intensification is doubtless from the scientific rationale of the state forest policy, which assists highly possible for transference of forestry increase to the innovative basis and demands general-theoretical analysis of the key issues. The exhaustion of forest resources is global in nature, but we should manage forests in keeping with national interests. The problem is: more productive forests are unstocked first and then it comes to the use of worse quality forests. This situation is particularly characteristic of the European North Russia including the Arkhangelsk, Vologda, Murmansk regions, the Republics of Komi and Karelia. This problem usually involves large expenses. The exhaustion of forest resources results in the fall of productive forces, which causes an urgent need of updating the overall regeneration system in the forest sector of the economy. As the value of forest resources grows, they demand the development of innovational technologies for more productive, more careful use.

It is reasonable to classify the approaches to forest resource management according to the number of the forests values (functions) are used. In keeping with the specified classification attributes the approaches to management of forest resources can be divided into the following categories: monofunctional - one kind of forest resources (wood as raw material) is used, and multifunctional - maximum functions are applied with optimal parity of the kinds of use in a specific organization of facilities.

Let's briefly describe the mathematical model of realization of the monofunctional approach. For this purpose, we shall take advantage of the concept of direct (Cartesian) product [1]:

$$
A=K_{\mathrm{T}} \times K_{\pi},
$$

where $A$ is linear transformation standing for a set (chain) of produced valuable goods and services (volume of forest income); $K_{\mathrm{T}}$ is transformation of monofunctional forest use, consuming wooden raw material; $K_{\text {л }}$ - transformation of the monofunctional forestry delivering the wooden raw material.

With this approach the volume of consumption of the productive capital in the forest grows, and, consequently, the productive potential of the forests is reduced, the forests' biological value is exhausted (emergence of deciduous forests instead of coniferous).
The mathematical mechanism describing the multifunctional approach, can also be based on the concept of Cartesian product:

$$
A=\sum_{i=1}^{n} K_{\text {ті }} \times \sum_{i=1}^{n} K_{\text {лі }},
$$

where $K_{\text {ті }}$ is transformation of multifunctional forest use; $n$ - number of the types of use; $K_{\text {лі }}$ is transformation of multifunctional forestry.

The comparison of models (1) and (2) helps to draw a conclusion that with the multifunctional approach, the volume of the forest's productive capital (forest ecosystem's assets) is maintained, supplying with a flow of valuable goods and services in the future.

Everything of the mentioned above can be referred to the application of the so-called multifunctional process, which has no waste products. Such multifunctional processes exist in nature; therefore, they function with no signs of exhaustion of raw material. The key idea of the multifunctional process is the concept of a variety of forestry practices when forestry functions are considered from wider standpoints. Multifunctionality means that the forest production can be grown (regenerated) indefinitely on a rotational basis, each time increasing the productive potential of the forest land, improving the quality of the forest's various functions and materials produced.

The analysis of MFFE development is impossible without the support of a fundamental theoretical base. In the political-economic analysis, it is essential to find common features for the circulation of all the forestry functions, due to which it becomes possible to unite them in a general uniform process of innovational forestry practices. It results in the creation of a special form of innovation - gross innovational forestry product. First, the constant movement of new forms of management in reply to modern trends of global changes when forestry is forced to transfer the centre of gravity in management from resource position to ecological position, with the consumer value of services in relation to the current labour expenses being of paramount significance. Second, in connection with diverse utility values of forest resources and changing from a natural state into a form of a public product they are embodied, not in an individual consumer cost (plenty) but, in a special form of innovation - gross innovational forestry product as a complex of physical-material benefits (single) (forest resources and ecosys- 
tem services being also implied). Here, the single and plenty and are in logically inherent contradiction, antinomy, since the single cannot exist without the plenty and requires it, and the plenty is too something of a single. This contradiction is logically synthesized in a new category, in a cluster as a whole. Thus, cluster as a whole is a dialectic synthesis of «single» and «plenty». The more is the sum of material benefits created at the same size of initial forest resources the more rationally is the society directs the circulation of the forest capital. If during the perspective time period the amount of expenses per unit consumer cost of the benefit is reduced.

For the entire national economy on the whole with its various requirements it is not the separate material benefits and the amount of their expenses but the total set of consumer costs is of paramount importance. The transformation into it is essentially the movement of the forest capital. It is also important first of all to consider the socially indispensable labour expenses for the total set of produced benefits and services, including the regeneration of forest resources.

Therefore, the circulation of the forest capital should be treated as critically important both in the theory and in practice of modern economics. It is in the system of material benefits and services (the circulation of the forest capital is a factor forming a system), but not in the single benefits that the character of interrelations of society and the forest is expressed. It should become a major item due to which there develop socioeconomic and ecological attitudes, and it is the initial point in the organization of sustainable development of the economy's forestry sector.

On the basis of factors stated above the circulation of the forest capital could be presented as unity of movement of customer cost and labour:

$$
\begin{gathered}
\text { Circulation } \\
\text { of forest } \\
\text { capital }
\end{gathered}=\left\{\begin{array}{c}
\text { Circulation of forestry functions } \\
\text { (total of benefits and services) } \\
\text { Flow of social labour } \\
\text { (socially required expenses) }
\end{array}\right.
$$

The flow of social labour is the total fund of working hours systematically directed for the production of the required customer costs and reproduction of the required customer costs and regeneration of forest resources. In modern conditions, there is an imperative need in the definition of reasonable requirements, preservation of the ecosystem services, and it is presumably the main value of the postindustrial society, formation of the strategic objectives of forest management gradually approaching them by means of increasing rationalization of the forest capital circulation.
The MFFE optimization is linked with the observance of some most general conditions as constituents in the relations of a system. First, it is necessary to abandon the concept of basic and collateral functions. Besides the function of resource maintenance, the multipurpose forestry has at least three more important functions, which can be underestimated in no event. They are ecosystem services supporting ecological sustainability: "spiritual" services connected to aesthetic, cultural, historical, ethical aspects of consumption, services in maintenance of health, i.e. everything considered as the main values of the postindustrial society. Hence the basic types of multifunctional management possibly include ecological tourism, gathering and processing of wild-growing fruits, berries and medical herbs; ecological hunting; fishery and related services; woodworking and construction; storage, processing of wildgrowing fruits to supply the regional demand etc. In the process of circulation of functions, neither of the modifications should be treated to the detriment of other properties. Second, in the framework of circulation public expenses for every consumer cost should not to be reduced intentionally. It is the end result that is important - a minimum on the entire process considering its influence on the preservation of ecological landscape and historical unity of forest ecosystems - all factors representing the main values of postindustrial society. And, third, the economy and the organization of MFFE should function in the interests of the population.

Thus, the problem of MFFE can be expressed using dualism of Descartes in achieving the magic formula, which is being searched by all of us: Pluralism $=$ Monism. Such a diverse network of forestry functions («fabric from patches») is opposite to a centralized system, and at the same time it provides a special vision of forestry, special "monism", which results in the creation of special forms of innovation - gross innovational forestry product. The essence of the formula is viewed as follows: the entire diverse utility of a forest can be reproduced only as a single unity, representing a set of ecological systems of various territorial levels, from regional to global, as the main means of both production and life. Pluralism provokes the problem of implementation of the fundamental paradigm in forestry - variety, meaning the academic standard of physical, political, ecological, social, economic and spiritual wellbeing of the forest ecosystems.

The above-considered model generally helps to predict the morphological characteristics of innovation products in complex systems on the ba- 
sis of a complete description of dual characteristics of the forest sphere and the processes developing there. The problem in attaining this formula is that for a long period guiding principle was the opposite - monism in forest use - the doctrine of typically colonial forest use on the basis of clear cutting concentrated felling which has resulted in exhaustion of northern forests.

Also, it is obviously necessary to draw attention to the problems of increase in the consumer cost and quality of MFFE to understand why they do not take a due place in forestry practices, to show the importance of their function in the reform strategy in the forest sector, especially in the modern times under new market conditions and also when constituting a forest policy.

It is well-known that after the publication of the first volume of Capital K. Marx marked that the best point in his book is the dual character of labour underlined as early as in the first chapter, duality depending on whether it is expressed in consumer cost or exchange value [5, p. 377].

Under present conditions when there is an urgent need in the substantiation of a system of measures on sustainable development of the economy's forest sector, in attaining conformity of cost and natural-material proportions, the dialectic interrelation of two kinds of labour (dualism), embodied in consumer cost of goods and expenses of total public resources for their manufacture, demands a deeper theoretical research. In our opinion, without that it would be difficult to realize the modern concept of synthesis of two institutions: the government and the market, which are also of the dual nature.

The essence, the chief characteristics of consumer cost of forest resources is expressed with the quality which has approximately the same distinction with the latter as cost of the goods and level of expenses for necessary social labour per unit of production. The quality of the wooden raw material is of special significance in connection with its deficiency and impossibility to increase the resources in a short term.

In the classical definition of the cost of goods, given by K. Marx, the quality is present and influences its essence and completeness, “...cost of any goods is determined by the working hours required for the manufacture of goods of proper quality" [4, p. 84].

Thus, the bases of research methodology of such complicated economic categories as quality of production, labour, services incorporated in Capital are of general character.

In fact, as normal quality MFFE[1] indirectly confines the process of individual expenses for the organization MFFE to those socially demanded, developing on the market, i.e. those taking into account the interests of the entire society and developing on the basis of the concept of sustainable development of the forest sector. Hence follows an important conclusion that the normal quality MFFE is a level of socially demanded quality determined by the level of development of productive forces and the corresponding level of development of the people's needs. All depends on the preferences of society and relative value [2] of the benefits provided by MFFE.

The forest plot turns into a productive force attractive to the investor only when it is jointly prepared for development, is completely provided with an industrial, transport and social infrastructure, qualified staff, automobiles and instruments for work, preparation of subcompartment databases for plots of land and cartographical basis.

In conditions of competition, the barter relations are governed not only by the socially required expenses on resources, but also by socially demanded quality of forest resources. This competition provides a significant reduction of expenses or improvement of quality. The commodity producer who manufactures goods of a better than socially required quality finds himself in a more advantageous position and the forest market he gets an opportunity to sell the goods (services), new goods (services) of better quality at higher prices due to the increased demand for them.

[1] First of all, the repeated use of the entire complex set of resources and services of the forest are meant, including non-wooden forest utilities and recreational functions of a forest when developing one and the same rented site of the forest fund.

[2] Unlike cost value synthesizes in itself: first, the significance of production (in all its possible many-sided nature) for the satisfaction of needs of a person and, second, expenses of labour (in money terms - the price of goods for the purchase of the production).

The commodity producer who provides goods (services) of quality below than socially required, for example, turning out production with out-ofdate technologies, under other equal conditions he incurs losses, being compelled to sell the production at comparatively lower prices. Otherwise because of absence in demand for products of lower quality he is unable to sell it, and that results in complete bankruptcy. Certainly, this is a schematic description suggesting a general idea of the principal laws in the relations between the quality of forest resources and their exchange 
value (price) and thus the unity of the two aspects of the goods is accepted.

In practice, there are contradictions between them and this unity results from the coordination of interests of the subjects of forest relations: the forest owner (state), forest user and society in the process of forestry activities, which is to be to provided anew each time. And wherever it is well organized and works better, the forestry functions more effectively and is competitive. Today as never before deep analysis of competitive advantages of the Russian forest sector is necessary.

In modern conditions under the influence of continuous innovations connected with the introduction of new goods, a new technology, a new source of raw material, a new type of the organization, there was a major shift in the concept of competition, according to the definition of Schumpeter [7]: the quality of forest resource use keeping in mind the necessity of their advancing regeneration, quality of products and services of a forest turned into one of decisive factors of expanded reproduction. The more is the sum of material benefits created with the same amount of initial resources of the forest the more rational is the circulation of the forest capital.

Therefore, it is possible to assume that in the sustainable development of the economy's forest sector, there is a well defined tendency - an objective economic law of "harmonious unity and interaction of two basic principles in forest use: multifunctional use of forest resources and the volume of their engagement in economic circulation". In the process of regular increase of quality of resource use and forest services, fewer resources are involved in economic circulation than nature and society can reproduce during a certain period, and nevertheless the gross forest profit would grow at more and more higher rates. Thus, the expenses for the economy of a unit of a resource have limits determined by the expenses per unit of extracted resource. The idea of transition of quantity into quality can be traced in labour too [6]. Academician G. A. Mesyats expressed its essence in a brief and concise way: from the times of the industrial revolution progress meant an increase of labour productivity. "Factor four" offers a new approach to progress, regarding as a cornerstone the increase of resource efficiency. In a broad sense, the quality of forest resource use involves the process of consumer cost increase for the forest's products and services in the context of improving the needs of people and the society on the basis of developing a multipurpose forest economy, capable of producing a huge variety of forestry products and services, sticking to the key idea the evolutionary theory of sustainable development - the idea of the variety. The value of natural forests in meeting global demand is getting restricted more and more to the area of preservation of biodiversity and climate on the planet. We are in need of a great variety of species of plants and animals, skills and methods, variety of people ideally adapted to use forests in the best way. In this essentially reproductive process, there is modernization of existing consumer costs which leads to exhaustion of forests and the creation of new goods and services in the forests meets the requirements of sustainable development and the level of contemporary needs. Thus, the needs under the conditions of MFFE acquire more and more a system-synergetic character, and for their successful satisfaction they need interaction, reciprocal complementation of many consumer costs, which contribute to the emergent effect. From all that it follows that the improvement of the quality of using the entire system of functions performed by forestry, including each separate piece of goods and service as an element of this system should meet the needs of perfection and growth of the people's demands.

In connection with the above stated information, two important laws of development of modern forest relations should be emphasized. First, on the basis of the theory of social development, which holds true for any social system, stressing the principal role of progress in productive forces it is possible to draw a conclusion that exactly the steady tendency for the improvement of quality of the forest as means of production for forestry purposes serves as a base line for the efficiency growth of the forest ecosystems. We shall consider well-known proportions of a social product of the forest sector with expanded reproduction, having applied letter designations, which $\mathrm{K}$. Marx used when analysing the problems of reproduction in Capital. The second subdivision of forestry production is represented in our example by non-wood forest resources:

$$
I(C+V+m)>I c+I I c .
$$

In our opinion, this condition should be considered not only from the quantitative, but also from the qualitative aspect. In particular, rate of quality or consumer value (productivity) should be higher than that of newly reproduced means of production (forest stands) in the long term (tendency), than that of replaced or removed plantings. It is impossible to obtain economic growth without effective renewal of the forestry-aimed fixed capital (forest stands) and mobilization for this purpose of the financial and material resources. 
Second, within the social production of the economy's wood sector there is an inherent need in maintaining conformity of regular improvement of quality, structure of the public consumer cost and the dynamics of the reduction of public expenses of resources for the manufacture of a unit of useful effect (consumer value) of the total end-product. This law can be presented as follows: the socially adequate rate of quality of wood resources amounts to the degree of socially required labour expenses for forest production and services.

The specified economic laws and regulations are determined by synthesis, interrelation and interaction of the quality of forest resources and the productivity of social practices in the economy's forest sector. Attaining the conformity of economic policy and the forest sector management system is getting urgent.

It is obvious that there should be more than just appeals to improve the quality of forest use and efficiency of Russia's forests. We are in need of a national thoroughly reasoned forest policy and a strategy for the improvement of the quality of forest resource use and reductions of the costs for the manufacturing of the end product and an effective system of their implementation at all levels of management.

As to the law of advanced improvement of the quality of the means of forestry-oriented production (forest stands) in comparison with the total growth of productivity of forest ecosystems, it is also ignored in many respects, which can be proved by the fast rates of reduction of wood stocks, especially in the last decades. In comparison with the 1950s, the stock stands for harvesting in the Arkhangelsk region and the Republic of Komi has decreased from 200-250 to 110-120 $\mathrm{m} 3$ per ha [2]. Therefore, the Komi region (obviously, very soon) will confront shortage of largesize commercial coniferous wood. At the turn of the centuries, the average stock of raw material in stands of basic types of forests never equaled half of the possibly available. It is even less (30-40\%) in habitats of highly productive woods (former ship groves). In the Arkhangelsk and Vologda regions these forested lands make almost a quarter of wood fund. The damage inflicted to forestry in these areas is obvious.
The novelty and advantage of multifunctionality of the economy's forest sector, forestry imply that they make it a vital component of forest spaces of northern regions capable of self-maintenance. That is realized through an effective technological system (innovational cluster) as a complex of decentralized branches of small scale for processing products of wood. It is possible to solve the urgent problem of depopulation in forest regions through establishing multipurpose forestry, which can carry out forest regeneration alongside with harvesting and use of other forest values. Multifunctionality is aimed at the preservation of the main biospheric function of the forest ecosystem in the European North - to maintain the circulation of carbon dioxide and oxygen providing global stability of climatic conditions.

Therefore, from our point of view, the modernization of the forest regeneration process is extremely important both in the theory and the practice of modern forest economy. In connection with diverse uses of forest resources, they are represented not in an individual consumer cost but in complex totality of the forest's material and physical values when transformed from a natural state into the form of a public product. The means of production used in forestry, consumer goods, direct natural social living means of the forest land population are included here. It is in the system of the forest's material benefits and services that the nature of the interrelations of society and the forest is expressed. It should become the basic point contributing to the establishment of forest relations and the initial point for the organization of sustainable forest management.

Thus at the heart of the Concept of improvement of quality for the forest use in the European north which is to be developed in accordance with the new adopted state programme "Development of Forestry in Russia for the Period Until 20132020" [3] must be delivered to improve the quality of life of the population.

The paper is written within the framework of Russian humanitarian scientific fund (RGNF) grant No 12-12-11000 a (p) "Tools of Sustainable Management of the Forest Complex in the FinnoUgric Countries and Their Use in the Innovational Development of Northern Regions".

\section{References}

1. Bolshakov N. M., Zhideleva V.V. (2012). Kontseptualnye osnovy ustoychivogo razvitiya regionalnogo lesnogo sektora: teoriya, metodologiya, praktika [Conceptual Bases of Sustainable Development of Regional Forest Sector: Theory, Methodology, Practice]. Izvestiya Komi nauchnogo tsentra UrO RAN [News of Komi of centre of science of Urals Department of the Russian Academy of Sciences]. Issue 4 (12), 100-106. 
2. Weizsecker E., Lovins E., Lovins L. (2000). Faktor chetyrye. Zatrat - polovina, otdacha - dvoynaya. Novyy doklad rimskomu klubu [Factor Four. Expenses - Half, Feedback - Double. The New Report to the Roman Club]. Tr. by A. P. Zavarnitsina and V. D. Novikova, edited by Acad. G. A. Mesyats. M. : Academia, 400 p.

3. Gosudarstvennaya programma "Razvitiye lesnogo khozayastva Rossii na 2013-2020 gody: utv. 30 dek. 2012 g." [state Programme "Development of Forestry in Russia for the Period until 2013-2020" : gr. 30 dec. 2012]. Lesnaya gazeta [Forest Newspaper]. 2013. 15 Jan.

4. Marx K., Engels F. (1969). Sochineniya [Collection of Works]. V. 23. M.: Politizdat.

5. Marx K., Engels F. (1969). Sochineniya [Collection of Works]. V. 31. M.: Politizdat.

6. Tsvetkov V.F. (2007). K kontseptsii uporyadocheniya i sovershenstvovaniya lesopolzovaniya na Yevropeyskom severe Rossii [To the Concept of Orderly Arrangement and Perfection of Forest Use in the European North of Russia]. Lesnoi zhurnal [Forest Magazine]. № 1, 19-27.

7. Schumpeter J.A. (2007). Teoriya ekonomicheskogo razvitiya. Kapitalizm, sotsializm I demokratiya [The Theory of Economic Development. Capitalism, Socialism and Democracy]. M. : Exmo, 864.

\section{Information on authors}

Bolshakov, Nikolai Mikhailovich (Syktyvkar, Russia) - Doctor of Economics, Professor, Honoured President of the Syktyvkar Forest institute (branch) of federal state budgetary educational establishment of higher vocational training «St.-Petersburg state forest technical university named after S. M. Kirov» (167982, Republic of Komi, GSP-2, Syktyvkar, 39 Lenin street, institut@sfi. komi.com).

Zhideleva, Valentine Vasilyevna (Syktyvkar, Russia) - Doctor of Economics, Professor, Director of the Syktyvkar Forest institute (branch) of federal state budgetary educational establishment of higher vocational training «St.-Petersburg state forest technical university named after S. M. Kirov» (167982, Republic of Komi, GSP-2, Syktyvkar, 39 Lenin street, institut@sfi.komi. com).

Ivanitskaya, Irina Ivanovna (Syktyvkar, Russia) - Candidate of Economics, Associate Professor, Head of the Department of Management and Marketing of the Syktyvkar Forest institute (branch) of federal state budgetary educational establishment of higher vocational training «St.-Petersburg state forest technical university named after S. M. Kirov» (167982, Republic of Komi, GSP-2, Syktyvkar, 39 Lenin street, institut@sfi.komi.com). 